\title{
Synthesis and Biologic Study of IV-14, \\ a New Ribonucleoside Radiotracer \\ for Tumor Visualization
}

Boris D. Zlatopolskiy*, Agnieszka Morgenroth*, Falk H.-G. Kunkel, Elizaveta A. Urusova, Cornelia Dinger, Thomas Kull, Christian Lepping, and Sven N. Reske

Klinik für Nuklearmedizin, Universität Ulm, Ulm, Germany

Uridine-cytidine kinase (UCK) 2, an enzyme normally expressed in human placenta and testis and highly overexpressed in many neoplasias of blood and solid tissues, catalyzes monophosphorylation of pyrimidine ribonucleosides with efficiency 15- to 20fold higher than that of ubiquitously expressed isozyme UCK1. In this paper, we report the synthesis of $3^{\prime}-(E)$-(2-iodovinyl)uridine (IV-14) and its preclinical evaluation as a new radiotracer derived from a UCK2-selective antitumor agent, 3' -(ethynyl)uridine. Methods: Radioiodinated IV-14 was prepared from the respective stannyl precursor. ${ }^{131} \mathrm{I}-\mathrm{IV}-14$ was studied in cellular uptake assays and tested for stability in serum as well as for stability to thymidine phosphorylase, liver-, and mucosa-specific murine uridine phosphorylases. UCK1 and UCK2 expression levels in different tumor cell lines were determined by Western blot. Cellular distribution of ${ }^{131} \mathrm{I}-\mathrm{IV}-14$ was determined in HL60 cells. Biodistribution studies and $\gamma$-camera scintigraphy were performed on an HL60-xenografted severe combined immunodeficiency (SCID) mouse model. Results: ${ }^{131} \mathrm{I}-\mathrm{IV}-14$ demonstrated excellent stability in serum. It was stable to human thymidine phosphorylase and to liver- and mucosa-specific murine uridine phosphorylases. Cellular uptake after $24 \mathrm{~h}$ of incubation with 131I-IV-14 was $4.27 \pm 0.21,3.66 \pm 0.13,2.69 \pm 0.07,2.24 \pm$ 0.18 , and $3.26 \pm 0.18$ percentage injected dose per $5 \times 10^{5}$ Mia-PaCa-2, CX-1, HL60, Capan-1, and Panc-1 cells, respectively. Uptake and retention of IV-14 were regulated by 2 factors: UCK2 expression level and intracellular transport mediated partially via human equilibrating nucleoside transporter 1 . A biodistribution study of ${ }^{131}$ I-IV-14 in an HL60-xenografted SCID mouse model showed that at $4 \mathrm{~h}$ after injection the greatest amount of retained radioactivity was in tumor. The tissue-to-tumor ratio 4 $\mathrm{h}$ after injection was $1.0 \pm 0.24$ for tumor, $0.40 \pm 0.18$ for spleen, $0.25 \pm 0.12$ for colon, $0.14 \pm 0.07$ for small intestine, and less than 0.1 for other sites. Scintigraphy with ${ }^{123}$ I-IV-14 $4 \mathrm{~h}$ after injection showed the tumor well. In addition, high accumulation of radioiodide in the stomach content was observed and was presumably due to metabolic degradation of IV-14. Conclusion: IV-14 is a UCK2-specific marker, allowing for in vivo addressing of tumors with high RNA synthesis independent of proliferation rate.

Received Apr. 29, 2009; revision accepted Jul. 22, 2009.

For correspondence or reprints contact: Sven N. Reske, Universität Ulm, Klinik für Nuklearmedizin, Albert-Einstein-Allee 23 D-89081, Ulm, Germany.

E-mail: sven.reske@uniklinik-ulm.de

${ }^{*}$ Contributed equally to this work.

COPYRIGHT ๑ 2009 by the Society of Nuclear Medicine, Inc.
Key Words: tumor targeting; ribonucleosides; uridine/cytidine kinase 2

J Nucl Med 2009; 50:1895-1903

DOI: 10.2967/jnumed.109.065623

$\mathbf{N}_{\mathrm{u}}$ umerous 2 -deoxyribonucleosides have been studied for imaging and radiotherapy of tumors in preclinical and clinical models (1-4). One of them, $3^{\prime}$-deoxy-3'-fluorothymidine (5), is already used in patients as a proliferation marker. However, little is known about the potential of radiolabeled ribonucleosides for application in this field. Only ${ }^{18} \mathrm{~F}$-5-fluorouridine was tested in vitro and in animal tumor models, and it demonstrated unfavorable biodistribution and low metabolic stability (6). The targeting of enzymes related to ribonucleoside metabolic pathways and RNA synthesis could be an attractive alternative to the already investigated targeting of thymidine kinase 1 , the key enzyme in the salvage pathway of deoxyribonucleosides and DNA synthesis. DNA synthesis occurs in the S-phase of the cell cycle. In contrast, RNA synthesis occurs in all cell cycle phases except the M-phase. Cellular uptake and metabolism of the marker independently of the cell cycle can be advantageous for imaging and radiotherapy of slowly growing solid tumors, which contain a smaller fraction of the cells in $\mathrm{S}$-phase than do rapidly proliferating tumors. In contrast to $3^{\prime}$-deoxy-3'-fluorothymidine, tracers targeted to RNA synthesis could also potentially be used for visualization of tumors with low thymidine kinase 1 expression.

$3^{\prime}$-(Ethynyl)uridine and $3^{\prime}$-(ethynyl)cytidine (Fig. 1) are highly cytotoxic against a broad spectrum of blood and solid tumors, with acceptable toxicity in normal tissues (7). $3^{\prime}$-(Ethynyl)cytidine is currently being tested in phase I clinical trials (8). 3'-(Ethynyl)uridine and $33^{\prime}$-(ethynyl)cytidine in the tumor cell are phosphorylated stepwise to their triphosphates, which inhibit RNA synthesis by nonselective blocking of RNA polymerase (Fig. 1) $(9,10)$. The ratelimiting monophosphorylation step is catalyzed by uridinecytidine kinases (UCKs) (11), mainly by UCK2 (12). 


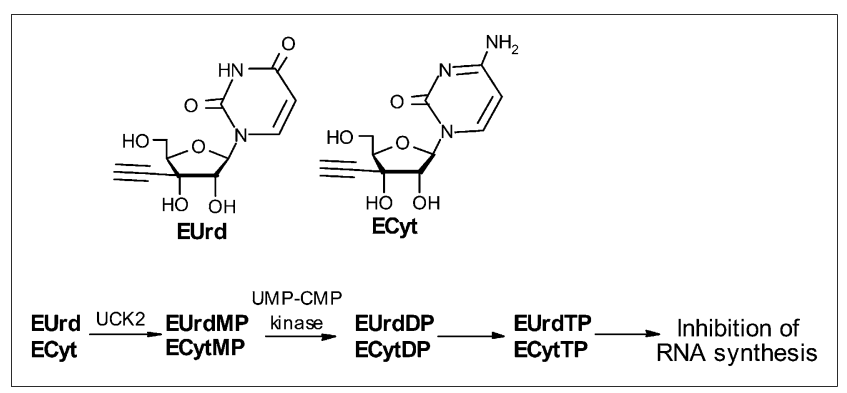

FIGURE 1. Structures of $3^{\prime}$-(ethynyl)uridine (EUrd) and $3^{\prime}$-(ethynyl)cytidine (ECyt) and metabolic activation of $3^{\prime}$-(ethynyl)uridine and $3^{\prime}$-(ethynyl)cytidine. UMP-CMP kinase $=$ uridine monophosphate/cytidine monophosphate kinase; $\mathrm{MP}=$ monophosphate; $\mathrm{DP}=$ diphosphate; $\mathrm{TP}=$ triphosphate.

UCK1 is ubiquitously expressed in normal tissues. In contrast, UCK2 is expressed only in the placenta (11) and testis (13). However, UCK2 is expressed in most human cancer cell lines studied (12). In another study (Annette Sommer, written communication, June, 2008), the messenger RNA level of UCK2 was found to be considerably higher in kidney, colon, breast, lung, and ovarian tumor tissues than in the adjacent normal tissues. Notably, uridine and cytosine phosphorylation efficacy is $15-20$ times higher by UCK2 than by UCK1 (11). We describe here the preparation and preclinical studies of the radioiodinated analog of $3^{\prime}$-(ethynyl)uridine.

\section{MATERIALS AND METHODS}

\section{Cell Lines and Reagents}

Pancreas Capan-1 carcinoma, colon CX-1 carcinoma, and HL60 leukemia (acute myelogenous leukemia) cells were obtained from DSMZ GmbH. Pancreas BX-PC-3, Mia-PaCa-2, Panc-1, and SK-PC-1 carcinoma cells were generous gifts from Prof. Stephan Hahn (Bochum, Germany). All cell lines were of human origin. Capan-1, CX-1, Mia-PaCa-2, and Panc-1 cells were grown in Dulbecco modified Eagle medium, high-glucose (Life Technologies, GIBCO), containing $10 \%$ fetal calf serum (Biochrom), $100 \mathrm{U}$ of penicillin per milliliter, and $100 \mu \mathrm{g}$ of streptomycin per milliliter (Life Technologies). HL60, BX-PC-3, and SK-PC-1 cell lines were cultured in RPMI 1640 medium (Biochrom) supplemented with $10 \%$ fetal calf serum, $100 \mathrm{U}$ of penicillin per milliliter, $100 \mu \mathrm{g}$ of streptomycin per milliliter, and $2 \mathrm{mmol}$ of glutamine per liter (Biochrom).

Chemicals and solvents were purchased from Sigma-Aldrich, Acrõs, and Merck or from other sources as indicated. All reagents and solvents were of the highest commercially available grade and used without further purification. No-carrier-added sodium ${ }^{131} \mathrm{I}$ iodide was obtained from Amersham Biosciences, and no-carrieradded sodium ${ }^{123}$ I-iodide was purchased from Zyklotron AG.

Synthesis of $3^{\prime}-(2-E)$-Tributylstannylvinyl)uridine (TBSVU) and $3^{\prime}$-(E)-(2-lodovinyl)uridine (IV-14)

Tributyltin hydride $(0.298 \mathrm{~g}, 0.93 \mathrm{mmol})$ was added to a suspension of $3^{\prime}$-(ethynyl)uridine $(0.25 \mathrm{~g}, 0.93 \mathrm{mmol}$; prepared from uridine in 5 steps as previously described (14)) in a solution of $\mathrm{Pd}\left(\mathrm{PPh}_{3}\right) \mathrm{Cl}_{2}(13 \mathrm{mg}, 19 \mu \mathrm{mol})$ in dry tetrahydrofuran $(30 \mathrm{~mL})$ under argon, and the mixture was vigorously stirred at ambient temperature. More tributyltin hydride was then added $(0.22 \mathrm{~g}$ [0.75 mmol] and 2 times $0.11 \mathrm{~g}$ [0.38 mmol] after 10,20 , and 40 $\mathrm{min}$, respectively), and the $3^{\prime}$-(ethynyl)uridine dissolved gradually to give a clear brown solution. After $1 \mathrm{~h}$, all volatiles were removed under reduced pressure and the crude product was purified by column chromatography on silica gel (first $\mathrm{CHCl}_{3}$ and then 15:3:1 $\left.\mathrm{CHCl}_{3}: \mathrm{EtOAc:MeOH}\right)$ to give TBSVU $(0.27 \mathrm{~g}$, $52 \%)$ as a faint yellow oil. $R_{\mathrm{f}}=0.12\left(15: 3: 1 \mathrm{CHCl}_{3}\right.$ :EtOAc: $\mathrm{MeOH}$ ) (for the spectral data, see the supplemental materials available online at http://jnm.snmjournals.org).

A solution of iodine $(36.3 \mathrm{mg}[0.143 \mathrm{mmol}])$ in $\mathrm{CH}_{2} \mathrm{Cl}_{2}(3 \mathrm{~mL})$ was added dropwise to TBSVU ( $80 \mathrm{mg}[0.143 \mathrm{mmol}]$ ) in $\mathrm{CH}_{2} \mathrm{Cl}_{2}$ $(3 \mathrm{~mL})$ over a period of $5 \mathrm{~min}$. Thereafter, pentane $(12 \mathrm{~mL})$ was added and the precipitate was separated by filtration. The crude product was purified by column chromatography on silica gel $\left(15: 3: 1 \mathrm{CHCl}_{3}: \mathrm{EtOAc:MeOH}\right)$ to give IV-14 $(45 \mathrm{mg}, 79 \%)$ as a colorless solid. $R_{\mathrm{f}}=0.18\left(15: 3: 1 \mathrm{CHCl}_{3}: \mathrm{EtOAc}: \mathrm{MeOH}\right.$ ) (for the spectral data, see the supplemental materials).

\section{Synthesis of $123 / 131$ IIIV-14}

Chloramine-T ( $5 \mu \mathrm{L}, 4 \mathrm{mg} / \mathrm{mL}$ in $66 \%$ methanolic solution) was added to a reaction vial containing no-carrier-added ${ }^{123 / 131} \mathrm{I}$ $\mathrm{NaI}(4 \mu \mathrm{L}, 159 \mathrm{MBq}$ in $0.05 \mathrm{M} \mathrm{NaOH}), 0.02 \mathrm{M} \mathrm{NaOH}(6 \mu \mathrm{L}), 2$ $\mathrm{M}$ phosphate buffer (10 $\mu \mathrm{L}, \mathrm{pH} 2$, in $30 \% \mathrm{EtOH})$, and TBSVU (2 $\mu \mathrm{L}$ of a $2.19 \mathrm{mg} / \mathrm{mL}$ solution in $66 \% \mathrm{MeOH})$. The reaction was stopped after 5 min by addition of $0.8 \mathrm{M} \mathrm{Na}_{2} \mathrm{~S}_{2} \mathrm{O}_{3}(20 \mu \mathrm{L})$. 123/131 I-IV-14 was purified by semipreparative high-performance liquid chromatography (HPLC) $\left(R_{\mathrm{t}}=11.8 \mathrm{~min}\right.$; eluent, $10 \% \mathrm{EtOH}$; flow, $1 \mathrm{~mL} / \mathrm{min}$; column, Kromasil [100 $\AA, 5 \mu \mathrm{m}, \mathrm{C} 4,250 \times 4 \mathrm{~mm}$; Eka Chemicals]). For isolation of the product, the fraction between 10 and 13 min was collected. The peak fraction was made isotonic using a $10 \% \mathrm{NaCl}$ solution and further diluted with isotonic saline to the desired activity concentration. Quality control was as follows: $R_{\mathrm{t}}=3.4 \mathrm{~min}$; eluent, $0.05 \mathrm{M}$ phosphate buffer in $60 \% \mathrm{MeOH}$; flow, $4 \mathrm{~mL} / \mathrm{min}$; column, Chromolith SpeedRod $\mathrm{RP}-18 \mathrm{e}(50 \times 4.6 \mathrm{~mm}$; Merck). Radiochemical purity was more than $99 \%$, and the radiochemical yield was $71 \%-82 \%$.

\section{Serum Stability Assay of ${ }^{131}$ [-IV-14}

To a solution of ${ }^{131} \mathrm{I}-\mathrm{IV}-14$ or ${ }^{131}$ I-iododeoxyuridine (IdU) (serving as a control) $(90 \mu \mathrm{L}$, about $7 \mathrm{MBq})$ were added $10 \%$ $\mathrm{NaCl}(10 \mu \mathrm{L})$ and normal human serum $(0.9 \mathrm{~mL}$; Sigma), and the mixture was incubated at $37^{\circ} \mathrm{C}$. Samples $(50 \mu \mathrm{L})$ were taken after $0,10,30,60,120$, and 1,440 min and treated with $1.5 \mathrm{M} \mathrm{HClO}_{4}$ $(50 \mu \mathrm{L})$. The precipitate was separated by centrifugation $(10,000$ $\mathrm{rpm}, 4^{\circ} \mathrm{C}, 10 \mathrm{~min}$ ), and the supernatant was analyzed by HPLC ( ${ }^{131}$ I-IV-14: see above; ${ }^{131} \mathrm{I}$-IdU: $R_{\mathrm{t}}=4.7 \mathrm{~min}$; eluent, $0.05 \mathrm{M}$ phosphate buffer; flow, $4 \mathrm{~mL} / \mathrm{min}$; the same column). The radiochemical yields of all reaction products were obtained as the relative peak area fraction of the sum of all areas in the radiochromatogram. Completeness of elution was checked by analyzing the same sample amount choosing a column bypass.

\section{Thymidine Phosphorylase Assay}

Susceptibility of IV-14 and IdU to glycosidic bond cleavage by thymidine phosphorylase was studied as follows. To a solution of human recombinant thymidine phosphorylase $\left(10^{-6}-0.1 \mathrm{U}\right.$; Sigma) in $0.17 \mathrm{mM}$ potassium phosphate buffer $(100 \mu \mathrm{L}, \mathrm{pH}$ 7.6), a solution of ${ }^{131} \mathrm{I}$-IV-14 or ${ }^{131} \mathrm{I}$-IdU (about $1 \mathrm{MBq}$ ) and nonlabeled IV-14 or IdU ( $3 \mathrm{nmol})$ in the same buffer $(225 \mu \mathrm{L})$ was 
added and the mixture was incubated at $37^{\circ} \mathrm{C}$ for $30 \mathrm{~min}$. Trifluoroacetic acid (TFA) $(30 \%, 30 \mu \mathrm{L})$ was added, and the mixture was cooled to $4^{\circ} \mathrm{C}$ and analyzed by HPLC as described above.

\section{Uridine Phosphorylase Assay}

Susceptibility of IV-14 and uridine to glycosidic bond cleavage by uridine phosphorylases was studied as follows. ${ }^{131} \mathrm{I}-\mathrm{IV}-14$ (2 $\mathrm{MBq})$ was incubated with liver or mucosa homogenate $(1.2 \mathrm{mg}$ of protein (15); see the supplemental materials for details on preparation) in $20 \mathrm{mM}$ potassium phosphate buffer $(\mathrm{pH}$ 8.0) with $1 \mathrm{mM}$ ethylenediaminetetraacetic acid and $2 \mathrm{mM}$ 2-mercaptoethanol $(500 \mu \mathrm{L})$ at $37^{\circ} \mathrm{C}$ for $2 \mathrm{~h}$. The reaction mixture was treated with $1 \mathrm{M}$ phosphoric acid ( $2 \mu \mathrm{L})$, transferred into Microcon YM-3 devices (Millipore) with a cutoff of $3 \mathrm{kDa}$, and centrifuged at $11,000 \mathrm{rpm}$ and $4^{\circ} \mathrm{C}$ for $25 \mathrm{~min}$. The supernatant was analyzed by HPLC (eluent A, water [0.1\% TFA]; eluent $\mathrm{B}$, acetonitrile [0.1\% TFA]; gradient, $0-1 \mathrm{~min}: 100 \% \mathrm{~A}, 10 \mathrm{~min}: 50 \% \mathrm{~B}$; $10-15 \mathrm{~min}$ : $50 \% \mathrm{~B}$; flow, $1 \mathrm{~mL} / \mathrm{min}$; column, Nucleosil C18 HD [250 $\times 4.6$ $\mathrm{mm}$; Macherey-Nagel]; $R_{\mathrm{t}}=11.3 \mathrm{~min}$ for ${ }^{131} \mathrm{I}-\mathrm{IV}-14,8.9 \mathrm{~min}$ for metabolite 2, and $9.6 \mathrm{~min}$ for metabolite 1).

Uridine $(8.4 \mu \mathrm{g}, 34.4 \mathrm{nmol})$ was incubated in the same mixture and under the same conditions. After ultrafiltration, the supernatant was analyzed by HPLC (eluent A, $0.05 \mathrm{M} \mathrm{NaH}_{2} \mathrm{PO}_{4}[\mathrm{pH}$ 4.15]; eluent $\mathrm{B}, 50 \% \mathrm{MeOH}$ in $0.05 \mathrm{M} \mathrm{NaH}_{2} \mathrm{PO}_{4}$ [pH 4.15]; gradient, 0-3 min: 100\% A, 13.6 min: $100 \% \mathrm{~B}$; flow, $1 \mathrm{~mL} / \mathrm{min}$; column, Gemini C18 [250 × $4.6 \mathrm{~mm}$; Phenomenex $] ; R_{\mathrm{t}}=11.3$ min for uridine and 7.2 min for uracil; detection, ultraviolet $[\lambda=$ $254 \mathrm{~nm}$ ] plus diode matrix array).

\section{Cellular Uptake of ${ }^{131}$ I-IV-14}

Cells $\left(5 \times 10^{5} /\right.$ well $)$ were seeded into 12 -well plates $24 \mathrm{~h}$ before the beginning of the experiment. ${ }^{131} \mathrm{I}-\mathrm{IV}-14(100 \mathrm{kBq})$ in assay medium $(1 \mathrm{~mL})$ was then added to the cells and incubated for 2,4 , and $24 \mathrm{~h}$ at $37^{\circ} \mathrm{C}$ and $5 \% \mathrm{CO}_{2}$. After incubation, the medium was removed and the cells were washed with ice-cold phosphatebuffered saline (PBS; $2 \times 1 \mathrm{~mL}$ ). Suspension cells were spun down by $1,200 \mathrm{rpm}$ for $5 \mathrm{~min}$ at $4^{\circ} \mathrm{C}$ between the washing steps. The cell pellet was resuspended in $1 \mathrm{M} \mathrm{NaOH}(1 \mathrm{~mL})$, and the radioactivity was measured in a $\gamma$-counter (Cobra II 5003; Perkin-Elmer [Packard]). In the respective experiments, cells $\left(5 \times 10^{5} /\right.$ well $)$ were preincubated with 5-fluoro-2'-deoxyuridine $(0.01 \mathrm{nM})$, p-nitrobenzylmercaptopurine $(10 \mu \mathrm{M})$, or 5-fluorouridine $(20 \mathrm{nM})$ for $1 \mathrm{~h}$ before incubation with ${ }^{131} \mathrm{I}-\mathrm{IV}-14$.

\section{Cellular Distribution of ${ }^{131}$ I-IV-14 in HL60 Cells}

A cellular distribution study was performed as previously described for ${ }^{125} \mathrm{I}$-ITdU in LL/2 cells (16). Briefly, HL60 cells were incubated with $100 \mathrm{kBq}$ of ${ }^{131} \mathrm{I}-\mathrm{IV}-14$ for 2,4 , and $24 \mathrm{~h}$. Thereafter, the cells were washed 2 times with ice-cold PBS and collected by centrifugation. The radioactivity uptake was measured using a $\gamma$-counter. Afterward, the cells were homogenized in ice-cold $0.2 \mathrm{M} \mathrm{HClO}_{4}(1 \mathrm{~mL})$. After being cooled on ice for 10 $\mathrm{min}$, the homogenates were centrifuged for $10 \mathrm{~min}$ at $1,200 \mathrm{~g}$ and $4^{\circ} \mathrm{C}$ to give a supernatant containing the acid-soluble fraction and a precipitate. The precipitate was resuspended with Type III Ribonuclease (Sigma) solution $(2 \mathrm{~mL}$ of a $0.66 \mathrm{mg} / \mathrm{mL}$ solution) and incubated at $37^{\circ} \mathrm{C}$. After $30 \mathrm{~min}$, ice-cold $5 \mathrm{M} \mathrm{HClO}_{4}(0.5$ $\mathrm{mL}$ ) was added. The probes were cooled on ice and centrifuged. The RNA-containing supernatant was separated, and the precipitate was resuspended in ice-cold $1 \mathrm{M} \mathrm{HClO}_{4}(1 \mathrm{~mL})$ and incubated for $15 \mathrm{~min}$ at $90^{\circ} \mathrm{C}$. After cooling and centrifugation, the DNA-containing supernatant was separated and the remaining protein and lipid fractions were washed once with $1 \mathrm{M}$ ice-cold $\mathrm{HClO}_{4}(1 \mathrm{~mL})$ and resuspended in ice-cold $1 \mathrm{M} \mathrm{NaOH}(1 \mathrm{~mL})$. The radioactivity of all samples was measured using a $\gamma$-counter. The purities of the isolated DNA and RNA fractions were measured at 2 wavelengths, 260 and $280 \mathrm{~nm}$, and the ratios of the 2 absorbencies were calculated. The $\mathrm{A}_{260} / \mathrm{A}_{280}$ ratio was about 2.0 for RNA and between 1.7 and 1.9 for DNA.

\section{Immunoblot Analysis}

For analysis of UCK2/UCK1 expression in tumor cell lines and mouse tissue, total protein lysates (spleen, small intestine, liver, and HL60 xenograft) were prepared by lysis with Tris. $\mathrm{HCl}$ buffer (50 mM; pH 7.4; NaCl, $300 \mathrm{mM}$; ethylenediaminetetraacetic acid, $2 \mathrm{mM}), \mathrm{NP}-40(1 \%)$, phenylmethylsulfonyl fluoride $(1 \mathrm{mM})$, and inhibitor cocktail (Roche). The protein samples were boiled for 5 min in reducing Laemmli buffer supplemented with 5\% 2-mercaptoethanol. Equal amounts of protein were subjected to electrophoresis (10\% Tris. $\mathrm{HCl}$ gel; Bio-Rad) and blotted onto polyvinylidene difluoride membrane (Bio-Rad). Immunostaining of UCK2 was performed with chicken polyclonal anti-UCK2 antibody (1:2,000; Abcam) and immunostaining of UCK1 with rabbit polyclonal anti-UCK1 antibody (1:2,000; Abgent). The secondary goat antichicken $\operatorname{IgY}(1: 2,000$, Abcam) and goat antirabbit IgG (1:5,000, Dianova) antibody coupled to horseradish peroxidase antibody were visualized with enhanced chemoluminescence (ECL+; GE Healthcare) as recommended by the supplier. Equal protein loading was controlled using glyceraldehyde 3-phosphate dehydrogenase (GAPDH)-specific antibody (1:5,000; Ambion) and secondary goat antimouse IgG linked to horseradish peroxidase (1:2,000; Abcam).

\section{Flow Cytometric Assay of Human Equilibrating} Nucleoside Transporter 1 (hENT 1 ) Expression on Tumor Cells

Cell suspensions were diluted to $1 \times 10^{6}$ cells $/ \mathrm{mL}$ with PBS for assay of total binding or with $5 \mu \mathrm{M} p$-nitrobenzylmercaptopurine in PBS for the assessment of nonspecific binding of the probe and kept at room temperature for $30 \mathrm{~min}$. 5'-[(Fluorescein-5ylcarbonyl)-6-aminohexanoyl-(2-aminoethyl)]- $N^{6}$-(4-nitrobenzyl)5 '-thioadenosine (SAENTA-x8-fluorescein; solution in 4\% dimethyl sulfoxide) (17) was then added to a $50 \mathrm{nM}$ final concentration, and incubation was continued for a further $20 \mathrm{~min}$ at room temperature. The cells were washed once with PBS, and the cellassociated fluorescence was measured using a FACSCalibur Flow Cytometer (BD Biosciences). Fluorescence signals from 10,000 cells were analyzed to determine the mean fluorescence intensity.

\section{In Vitro and In Vivo Metabolite Analysis}

After the incubation for 2, 4, and $24 \mathrm{~h}$ with ${ }^{131} \mathrm{I}-\mathrm{IV}-14$ (0.5-3.0 $\mathrm{MBq}$ ), the Mia-PaCa-2 cells (with or without 5-fluorouridine [20 $\mathrm{nM}$ ] pretreatment for $1 \mathrm{~h}$ ) were lysed as described above. After centrifugation at $10,000 \mathrm{rpm}$ and $4^{\circ} \mathrm{C}$ for $10 \mathrm{~min}$, the clear supernatant either was directly purified by ultrafiltration using Microcon YM-30 devices with a cutoff of 30 for $40 \mathrm{~min}$ at 12,000 rpm and $4{ }^{\circ} \mathrm{C}$ to remove protein residues or was first treated with calf intestinal alkaline phosphatase ( $1 \mathrm{U} / \mu \mathrm{L}$; Invitrogen) as follows. The supernatant $(350 \mu \mathrm{L})$ was charged with "10-fold dephosphorylation buffer" (50 $\mu \mathrm{L}, 50 \mathrm{mM}$ Tris. $\mathrm{HCl}$ [pH 8.5], 0.1 $\mathrm{mM}$ ethylenediaminetetraacetic acid) and calf intestinal alkaline phosphatase $(100 \mu \mathrm{L}, 100 \mathrm{U})$ and subsequently incubated for $2 \mathrm{~h}$ 
at $37^{\circ} \mathrm{C}$. Thereafter, samples were purified by ultrafiltration as described above. In vivo metabolite analysis was performed on animal urine, blood, stomach and stomach content, small intestine, liver, and tumor obtained from HL60-xenografted severe combined immunodeficiency (SCID) mice. Blood or urine samples (50 $\mu \mathrm{L})$ were charged with $200 \mu \mathrm{L}$ of aqueous heparin (100 IE). Liver, tumor, small intestine, and stomach $(100 \mathrm{mg})$ were homogenized in $10 \mathrm{mM}$ sodium-potassium phosphate buffer ( $\mathrm{pH}$ 6.8) with a Micro-Tissue homogenizer (Wheaton). Thereafter, samples were prepared as described above. Samples were analyzed by radio-HPLC. (Condition A: eluent $\mathrm{A}$, water [0.1\% TFA]; eluent $\mathrm{B}$, acetonitrile [0.1\% TFA]; gradient, 0-1 min: $100 \%$ A, $10 \mathrm{~min}: 50 \%$ B, 10-15 min: $50 \% \mathrm{~B}$; flow, $1 \mathrm{~mL} / \mathrm{min}$; column, Nucleosil C18 HD $\left[250 \times 4.6 \mathrm{~mm}\right.$; Macherey-Nagel]; $R_{\mathrm{t}}=11.2 \mathrm{~min}$ for ${ }^{131} \mathrm{I}-\mathrm{IV}$ $14,8.7 \mathrm{~min}$ for metabolite $1,5.0 \mathrm{~min}$ for metabolite $2,4.4 \mathrm{~min}$ for metabolite 3 , and 4.0 min for ${ }^{131} \mathrm{I}^{-}$. Condition $\mathrm{B}$ : eluent $\mathrm{A}$, water [0.1\% TFA]; eluent $\mathrm{B}$, acetonitrile [0.1\% TFA]; gradient, 0-12 min: $100 \%$ A, $20 \mathrm{~min}: 100 \% \mathrm{~B}$; flow, $1.8 \mathrm{~mL} / \mathrm{min}$; column, Gemini-NX C18 [250 $\times 4.6 \mathrm{~mm}$; Phenomenex $] ; R_{\mathrm{t}}=17.2 \mathrm{~min}$ for ${ }^{131} \mathrm{I}-\mathrm{IV}-14,15.9 \mathrm{~min}$ for metabolite $1,14.8 \mathrm{~min}$ for metabolites 2 and 3 , and 2.3 min for ${ }^{131} \mathrm{I}^{-}$. Condition $\mathrm{C}$ : eluent $\mathrm{A}$, water $[0.1 \%$ TFA]; eluent B, acetonitrile [0.1\% TFA]; gradient, 0-1 min: $100 \%$ A, $10 \mathrm{~min}: 50 \% \mathrm{~B}$; $15 \mathrm{~min}: 50 \% \mathrm{~B}$; flow, $1.0 \mathrm{~mL} / \mathrm{min}$; column, Gemini-NX C18 [250 $\times 4.6 \mathrm{~mm}$; Phenomenex $] ; R_{\mathrm{t}}=11.7 \mathrm{~min}$ for ${ }^{131}$ I-IV-14, $9.6 \mathrm{~min}$ for metabolite $1,8.9 \mathrm{~min}$ for metabolite 2, 8.2 min for metabolite 3 , and $4.0 \mathrm{~min}$ for ${ }^{131} \mathrm{I}^{-}$.) Metabolite 1 had a retention time identical to that of IV-14 monophosphate (for details on preparation, see the supplemental materials; Supplemental Fig. 1 compares metabolite 1 and nonlabeled IV-14 monophosphate by HPLC).

\section{Tumor Model}

A suspension of $4 \times 10^{6}$ HL60 cells was injected subcutaneously into the scruff of the neck, between the shoulders, of 6-wkold male and female C.B-17 SCID mice (Taconic). After 3 wk, subcutaneous tumors about $20-30 \mathrm{~mm}$ in diameter developed. All animal experiments were performed in accordance with national and local regulations for animal and radiation protection and good experimental practice.

\section{Biodistribution Study of ${ }^{131}$ I-IV-14 in HL60-Xenografted SCID Mouse}

Five megabecquerels of ${ }^{131} \mathrm{I}-\mathrm{IV}-14$ in saline $(200 \mu \mathrm{L})$ were injected into the lateral tail vein of C.B-17 SCID mice bearing xenotransplanted HL60 tumors. The mice were sacrificed at 1, 4, and $24 \mathrm{~h}$ after injection by cervical dislocation. Tumors and organs were excised, weighed, and assayed for radioactivity in a $\gamma$-counter. The contents of the stomach, small intestine, and colon were removed before weighing and measurement. Mean tumor and organ uptake was determined from half-life-corrected tissue radioactivity normalized to injected dose and tissue sample weight (percentage injected dose per gram of tissue [wet weight]).

\section{Scintigraphy with ${ }^{123}$ |-IV-14 in HL60-Xenografted SCID Mouse}

Imaging was performed using an e.cam $\gamma$-camera (Siemens Medical Solutions) coupled with a low-energy high-resolution collimator. Images of mice were recorded $4 \mathrm{~h}$ after IV application of $20 \mathrm{MBq}$ of ${ }^{123} \mathrm{I}-\mathrm{IV}-14$ under xylazine $(16 \mathrm{mg} / \mathrm{kg})$ and ketamine $(100 \mathrm{mg} / \mathrm{kg})$ anesthesia for $30 \mathrm{~min}$ using a 1,024 × 1,024 matrix, a zoom factor of 2 (pixel size, $0.3 \mathrm{~mm}$ ), and a $15 \%$ energy window centered at $159 \mathrm{keV}$.

\section{Statistical Analysis}

Uptake in the different cell lines was compared using the Mann-Whitney $U$ test. Differences were considered to indicate statistical significance for a 2-tailed $P$ value of less than 0.10 .

\section{RESULTS}

Radiosynthesis of No-Carrier-Added ${ }^{123 / 131}$ |-IV-14

${ }^{123 / 131} \mathrm{I}-\mathrm{IV}-14$ was obtained from TBSVU in $71 \%-82 \%$ radiochemical yield $(n=12)$ and in greater than $99 \%$ radiochemical purity. TBSVU was in turn stereo- and regiospecifically synthesized from 3 '-(ethynyl)uridine according to the Guibe-Zhang protocol (18) in 52\% yield (Fig. 2A) and was treated with iodine to give nonlabeled IV-14 in $79 \%$ yield.

\section{Stability in Serum and Susceptibility to Thymidine Phosphorylase- and Uridine Phosphorylase-Mediated Cleavage}

${ }^{131} \mathrm{I}-\mathrm{IV}-14$ was stable in serum for at least $24 \mathrm{~h}$. In the same period, IdU decomposed to about $30 \%$ of the initial quantity (Supplemental Fig. 2). ${ }^{131}$ I-IV-14 was also resistant to hydrolysis by thymidine phosphorylase, even at an enzyme concentration, which caused complete hydrolysis of IdU (Supplemental Fig. 3). ${ }^{131}$ I-IV-14 was also resistant to degradation mediated by the murine liver-specific uridine phosphorylase (liver homogenate was used as a source of enzyme). Incubation of ${ }^{131} \mathrm{I}-\mathrm{IV}-14$ with murine mucosa homogenates as a source of murine intestine-specific uridine phosphorylase caused only insignificant hydrolysis $(<2 \%)$. Under the same conditions, $47 \%$ and $90 \%$ of the initial quantity of uridine was hydrolyzed by liver- and intestine-
FIGURE 2. Synthesis of TBSVU, IV14 , and ${ }^{123 / 131} I-I V-14$. EUrd $=3^{\prime}$-(ethynyl)uridine; RP = radiochemical purity; $\mathrm{RCY}=$ radiochemical yield.
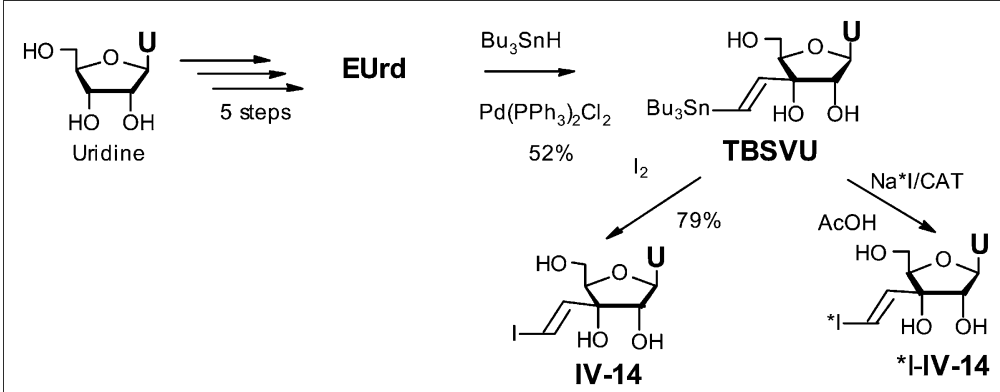

$\mathrm{RP}>97 \% \quad \mathrm{RCY}=87 \%-92 \%$ 
specific uridine phosphorylases, respectively, was hydrolyzed into uracil (data not shown).

\section{Cellular Uptake Studies}

${ }^{131} \mathrm{I}-\mathrm{IV}-14$ showed significant uptake into all tumor cell lines tested, except BX-PC-3 and SK-PC-1 (Fig. 3A). Both cell lines had low UCK2 expression and a low number of hENT $_{1}$ transporters on the cell surface. Consequently, the uptake was high for Mia-PaCa-2, Panc-1, Capan-1, and CX-1 cells expressing UCK2 at a high or moderate level (Fig. 3B) $(0.79 \%-2.24 \%$ at $2 \mathrm{~h}, 1.14 \%-2.30 \%$ at $4 \mathrm{~h}$, and $2.24 \%-4.27 \%$ at $24 \mathrm{~h})$. Concomitantly, an appreciable number of $\mathrm{hENT}_{1}$ transporter sites on the surface of these cells were detected by fluorescence-activated cell sorting with 5-(SAENTA-x8)-fluorescein, a cell membrane-impermeable inhibitor of $\mathrm{hENT}_{1}$ nucleoside transporters (Supplemental Fig. 4) (19). After $24 \mathrm{~h}$ of incubation, the accumulation of radioactivity in HL60 cells with relatively low UCK2 expression but with the highest number of extracellular $\mathrm{hENT}_{1}$ transporters among cell lines studied was significant $(2.69 \% \pm 0.07 \%)$ and even greater than in Capan-1 cells
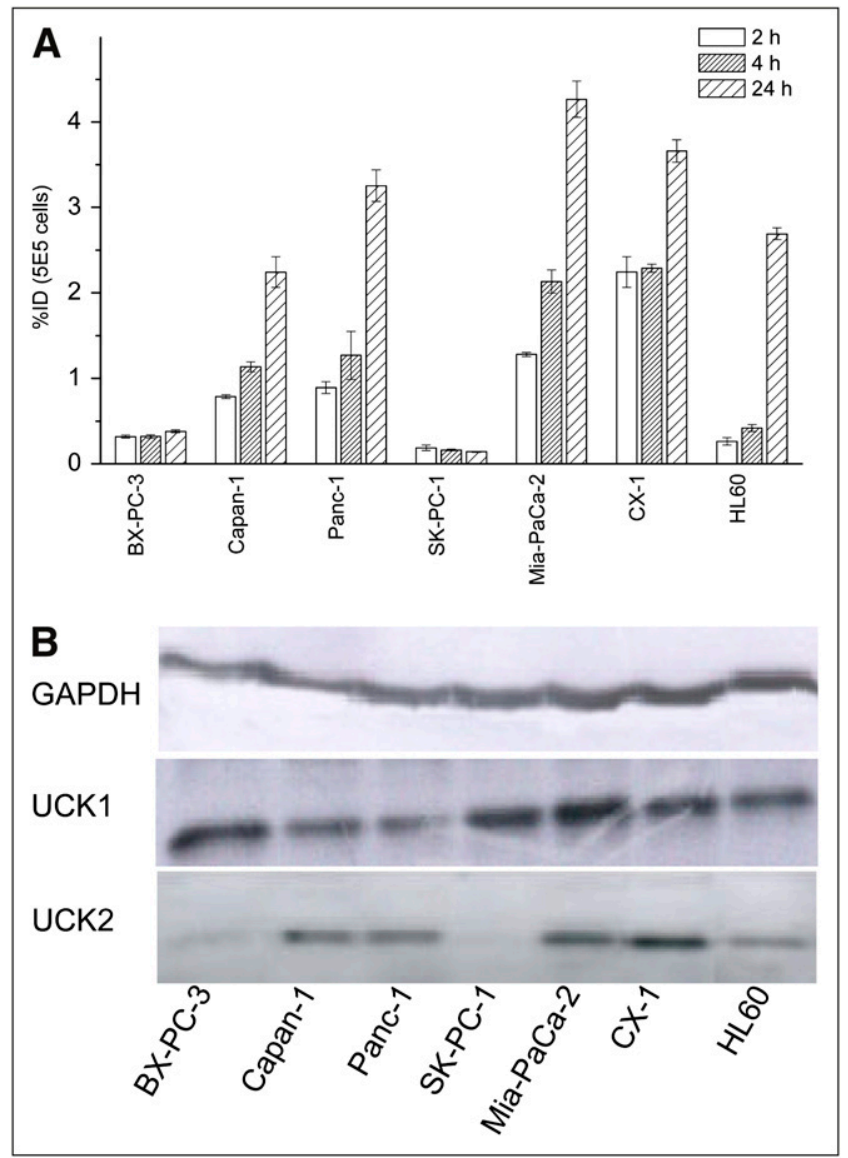

FIGURE 3. Cellular uptake of ${ }^{131} \mathrm{I}-\mathrm{IV}-14(100 \mathrm{kBq})$ in different tumor cell lines $(A)$ and Western blot analysis of UCK1 and UCK2 expression in tumor cell lines studied (B). Glyceraldehyde 3-phosphate dehydrogenase (GAPDH) expression is given as loading control. with higher UCK2 and lower $\mathrm{hENT}_{1}$ expression $(2.24 \% \pm$ $0.2 \%)$.

It was reported $(20,21)$ that pretreatment with nontoxic concentrations of the thymidylate synthase inhibitor such as 5-fluoro- $2^{\prime}$-deoxyuridine increased cellular uptake of $2^{\prime}$-deoxynucleosides such as ITdU and IdU in tumor cells. In contrast, uptake of ${ }^{131} \mathrm{I}-\mathrm{IV}-14$ in HL60 and Mia-PaCa-2 cells (Fig. 4A) was not increased by preincubation with 5-fluoro- 2 '-deoxyuridine. At the same time, uptake was partially inhibited by $p$-nitrobenzylmercaptopurine riboside, which is a highly selective inhibitor of $\mathrm{hENT}_{1}$ nucleoside transporter (22), in Mia-PaCa-2 and HL60 cells (up to $40 \%$ and $83 \%$ inhibition after $24 \mathrm{~h}$, respectively). Uptake of ${ }^{131} \mathrm{I}-\mathrm{IV}-14$ in both cell lines after $2 \mathrm{~h}$ of incubation diminished significantly after preincubation with 5-fluorouridine (up to $64 \%$ and $61 \%$ for Mia-PaCa2 and HL60 cells, respectively). However, this effect was much less pronounced after $4 \mathrm{~h}$ of incubation. After $24 \mathrm{~h}$, uptake in 5-fluorouridine-pretreated cells was virtually the same as in control cells. Uptakes under the different inhibition conditions after $2 \mathrm{~h}$ of incubation were statistically different $(P<0.1)$ in all cases. The only exception was uptake in HL60 cells with and without 5-fluoro-2' -deoxyuridine.

In HL60 cells incubated with ${ }^{131}$ I-IV-14, more than $90 \%$ of the radioactivity was detected in the cytosolic fraction (Fig. 4B). The incorporation rate in RNA was about $5 \%$. The associated radioactivity in DNA, protein, and lipid fractions was insignificantly low.

\section{Intracellular Metabolism of IV-14}

Pretreatment with 5-fluorouridine initially partially inhibited the metabolism of ${ }^{131} \mathrm{I}-\mathrm{IV}-14$ in Mia-PaCa-2 and HL60 cells. In Mia-PaCa-2 cells (Fig. 4C), about 30\% unmetabolized ${ }^{131} \mathrm{I}-\mathrm{IV}-14$ was observed after $2 \mathrm{~h}$ of incubation in the 5-fluorouridine-pretreated cells. At this point, only metabolite 1 could be detected in the untreated cells. After $4 \mathrm{~h}$ of incubation, only metabolite 1 was observed in 5-fluorouridine-pretreated cells and metabolite 2 was a main metabolite in control cells. After $24 \mathrm{~h}$ of incubation, a new metabolite, metabolite 3 , together with about $10 \%$ metabolite 1 was observed in the 5-fluorouridine-pretreated cells, and mainly metabolite 2 together with some metabolite 3 and metabolite 1 was observed in the untreated cells. All metabolites were completely hydrolyzed into ${ }^{131} \mathrm{I}-\mathrm{IV}-14$ by alkaline phosphatase (Fig. 4D). Retention times of metabolite 1 and nonlabeled IV-14 monophosphate were identical.

\section{Biodistribution of ${ }^{131}$ I-IV-14 in HL60-Xenografted SCID Mouse Model}

${ }^{131} \mathrm{I}-\mathrm{IV}-14$ accumulated at $0.5 \mathrm{~h}$ after injection in tumor as well as spleen and small intestine, and in nondividing tissues such as liver, stomach, and kidneys (Fig. 5A). At $4 \mathrm{~h}$ after injection, the most retained activity was accumulated in tumor tissue and spleen, whereas the radioactivity in residual normal tissues diminished progressively (Fig. 5B). At $24 \mathrm{~h}$ after injection, the radioactivity was almost completely excreted. 


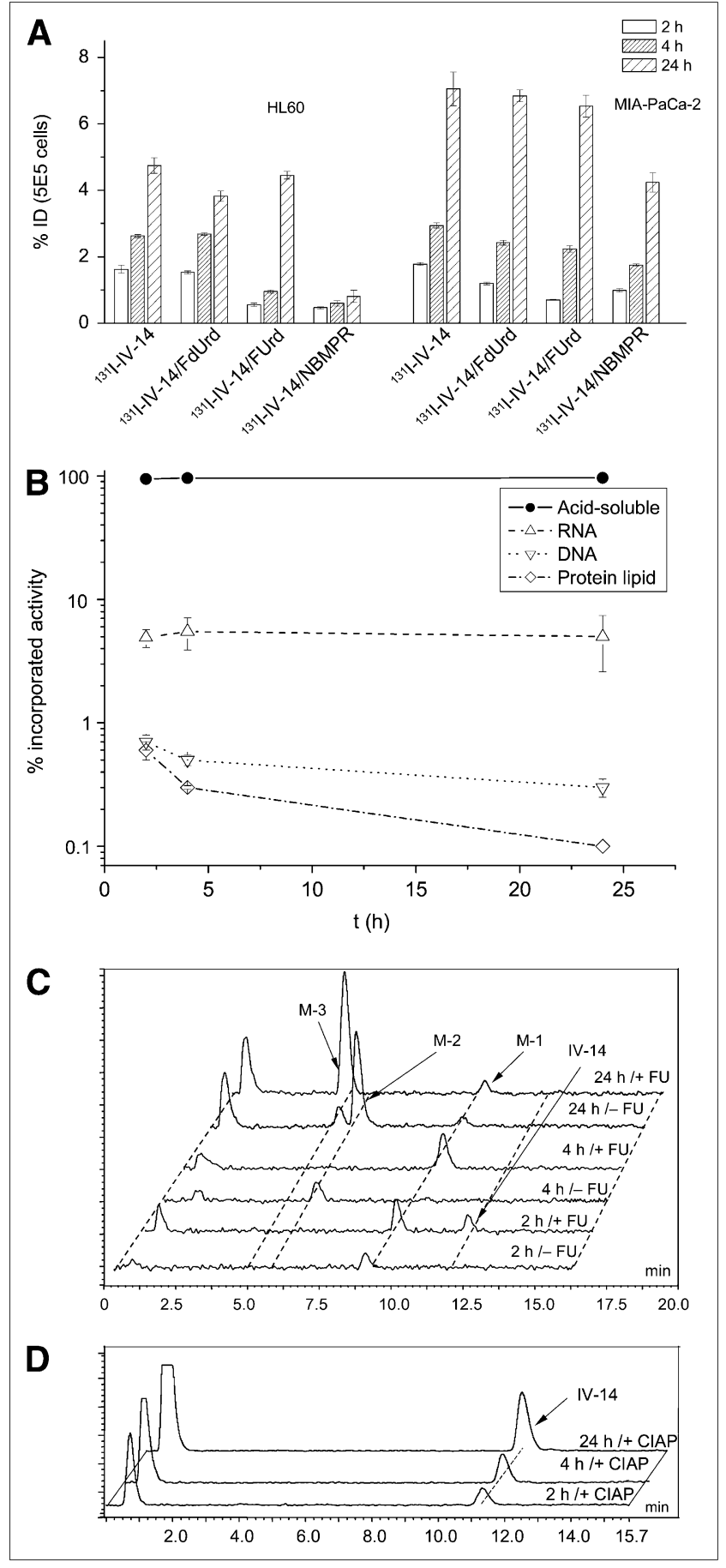

FIGURE 4. (A) Dependence of cellular uptake of ${ }^{131} \mid \mathrm{I}-\mathrm{IV}-14$ in HL60 and Mia-PaCa-2 cells on pretreatment with 5-fluoro2 '-deoxyuridine (FdUrd), 5-fluorouridine (FUrd), and p-nitrobenzylmercaptopurine (NBMPR). (B) Cellular distribution of ${ }^{131}$ I-IV-14 in HL60 cells. (C) Metabolism of ${ }^{131}$ I-IV-14 by MiaPaCa- 2 cells $(\mathrm{M}-1=$ metabolite $1 ; \mathrm{M}-2=$ metabolite $2 ; \mathrm{M}-3=$ metabolite 3 ). (D) Hydrolysis of $M-1-M-3$ by calf intestinal alkaline phosphatase (CIAP).
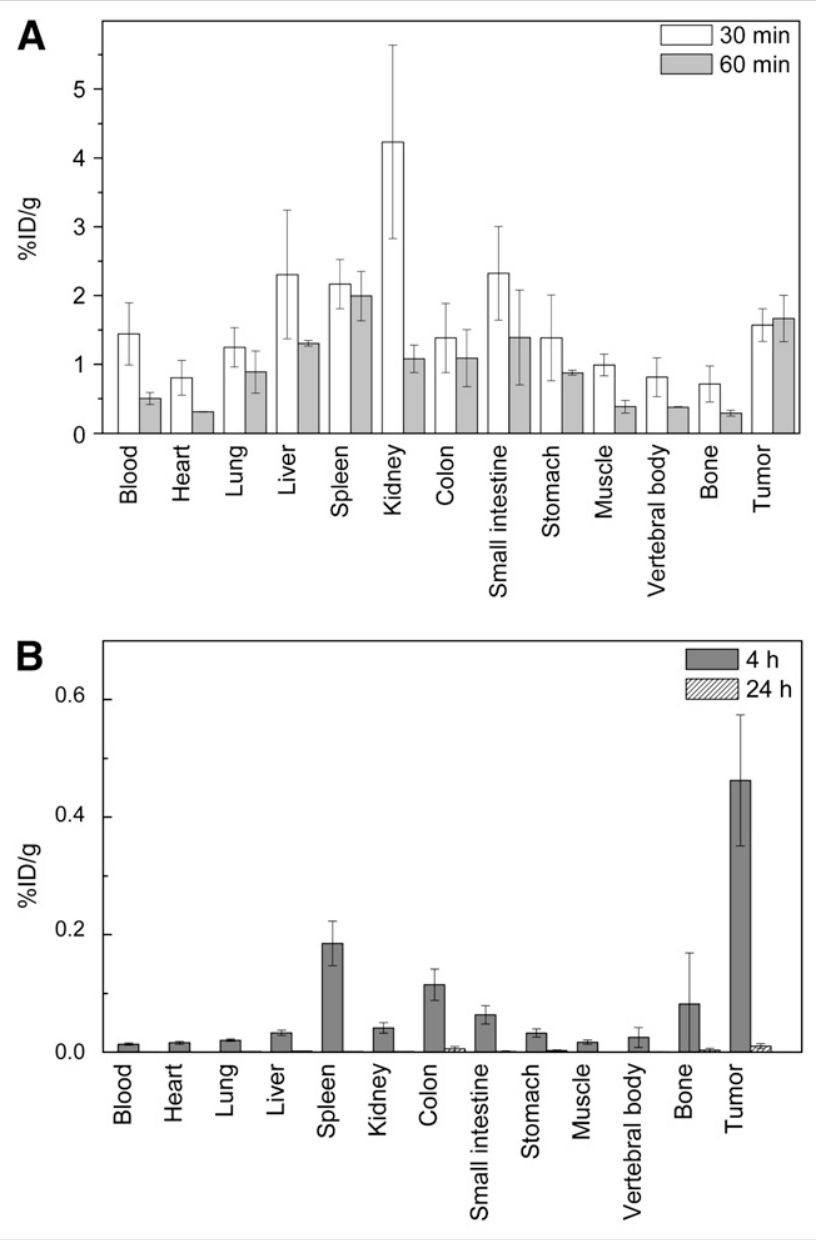

FIGURE 5. Biodistribution of ${ }^{131} \mathrm{I}-\mathrm{IV}-14$ (10 MBq) in HL60xenografted SCID mice 30 and 60 min after injection $(A)$ and 4 and $24 \mathrm{~h}$ after injection (B). Relative account of radioactivity/g in tissue divided by that in tumor (tissue-to-tumor ratio) $30 \mathrm{~min}$ after injection: tumor, $1.0 \pm 0.15$; kidneys, $2.69 \pm 1.30$; liver, $1.47 \pm 0.81$; small intestine, $1.48 \pm 0.66$; spleen, $1.38 \pm 0.44$. Tissue-to-tumor ratio $4 \mathrm{~h}$ after injection: tumor, $1 \pm 0.24$; spleen, $0.40 \pm 0.18$; colon, $0.25 \pm 0.12$; bones, $0.18 \pm 0.18$; small intestine, $0.14 \pm 0.07$; others, $<0.1$. Five animals were used at each time point.

\section{Scintigraphy with ${ }^{123}$ I-IV-14 in HL60-Xenografted} SCID Mouse Model

Scintigraphy with ${ }^{123} \mathrm{I}-\mathrm{IV}-14$ (4 h after injection) indicated good tumor visualization with no uptake in unblocked thyroid (Fig. 6). At the same time, high radioactivity enrichment in the content of the stomach and to some extent in the spleen was observed.

\section{Western Blot Analysis of UCK1 and UCK2 in HL60 Xenograft, Spleen, Small Intestine, and Liver}

Western blot analysis confirmed the expression of UCK2 in tumor tissue and its absence in normal tissues (spleen, liver, and small intestine). Nearly equal expression of UCK1 was detected in all 4 tested tissues (Fig. 6). 


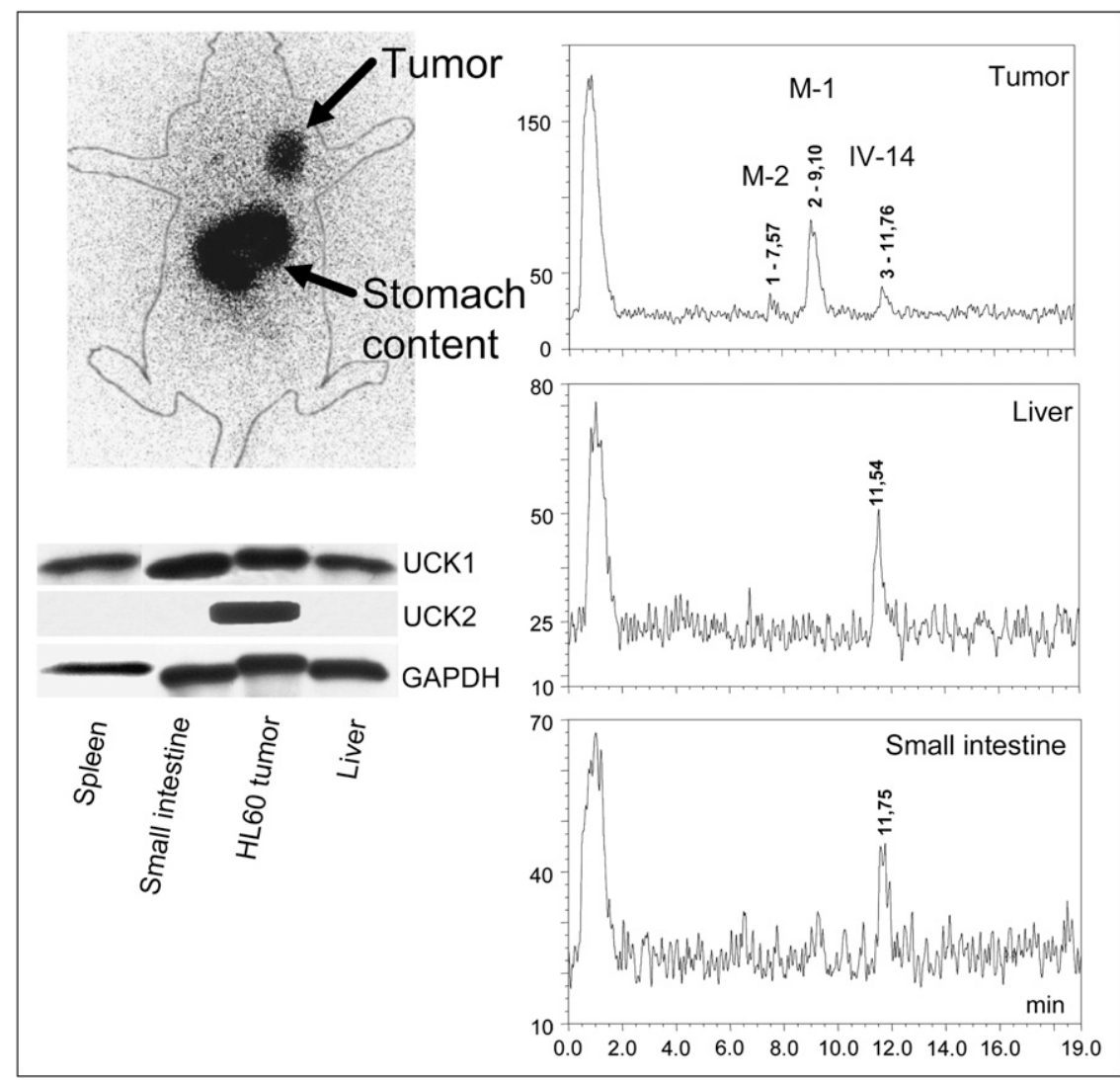

FIGURE 6. At top left is scintigraph obtained with ${ }^{123}$ I-IV-14 (20 MBq; 4 h) in 3 HL60-xenografted SCID mice. At bottom left is Western blot analysis of UCK1 and UCK2 expression in HL60 xenograft, spleen, small intestine, and liver tissues. Glyceraldehyde 3-phosphate dehydrogenase (GAPDH) was used as loading control. At right is analysis of metabolites of ${ }^{131}$ I-IV-14 (4 h after injection) in HL60-xenografted SCID mice. $\mathrm{M}-1=$ metabolite $1 ; \mathrm{M}-2=$ metabolite 2.
Metabolism of ${ }^{131}$ I-IV-14 in HL60-Xenografted SCID Mice (4 h After Injection)

Metabolite 1 (70\%), metabolite 2 (10\%), and IV-14 (20\%) were observed in tumor. Only IV-14 was detected in liver and small intestine (Fig. 6). Radioactivity in blood was below the detection limit. Equal quantities of radioiodide and IV-14 were detected in stomach content. Only unchanged IV-14 with traces of ${ }^{131} \mathrm{I}^{-}$was found in urine (for blood, stomach content, and urine data, see Supplemental Fig. 5).

\section{DISCUSSION}

IV-14 is a new ribonucleoside analog of uridine that targets tumor cells expressing UCK2. In the present work, IV-14 showed an UCK2-correlated uptake in a panel of tumors of human origin in vitro and preferential accumulation in UCK2-expressing xenografts in vivo. Thus, IV-14 is a promising candidate as an agent for diagnosis of cancer. The 3'-iodovinyl group allows switching between SPECT, PET, and radiotherapy agents simply by using different iodine radioisotopes $\left({ }^{123} \mathrm{I},{ }^{124} \mathrm{I}\right.$ and ${ }^{131} \mathrm{I}$, or ${ }^{125} \mathrm{I}$, respectively). Phosphorylation of nucleoside analogs is a prerequisite for the accumulation of IV-14 in tissue. A preferable phosphorylation of a ribonucleoside tracer by tumor-selective UCK2 and not by ubiquitously expressed UCK1 is important for selective enrichment in tumor tissue. The substrate efficiency $\left(\mathrm{V}_{\max } / \mathrm{K}_{\mathrm{m}}\right.$, where $\mathrm{V}_{\max }$ is maximum velocity and $\mathrm{K}_{\mathrm{m}}$ is the Michaelis constant) of the recom- binant UCK2 to $3^{\prime}$-(ethynyl)cytidine and 3 '-(ethynyl)uridine was reported to be about 2,000 times higher than that of UCK1 (12). We showed that ${ }^{131} \mathrm{I}-\mathrm{IV}-14$ was taken up mainly by the cell lines with high or moderate expression of $\mathrm{UCK} 2$, independently of expression of UCK1. Importantly, virtually no uptake $(<0.2 \%)$ was detected in the UCK2negative SK-PC1 cells. The first phosphorylation step catalyzed by UCK is considered rate-limiting (23). Notably, cellular uptake and retention suggested that IV-14 is phosphorylated in these cell lines. HPLC analysis of in vitro metabolites showed transformation of ${ }^{131} \mathrm{I}-\mathrm{IV}-14$ into 3 metabolites with higher polarity than the initial compound. We proposed that phosphorylation of ${ }^{131} \mathrm{I}-\mathrm{IV}-14$ could be a main route for its in vitro metabolism, with metabolites 1 , 2, and 3 corresponding to IV-14 mono-, di-, and triphosphates, respectively. Our assumption was supported by complete hydrolysis of all 3 metabolites by alkaline phosphatase, which gave IV-14 as a single product, and by the coincidence of retention times between metabolite 1 and nonlabeled IV-14 monophosphate.

5-Fluorouridine is a substrate for UCK1 and UCK2 with a substrate efficiency $\left(\mathrm{V}_{\max } / \mathrm{K}_{\mathrm{m}}\right)$ about 20 -fold higher for UCK2 than for UCK1 (11). Interestingly, after 2 and $4 \mathrm{~h}$ of incubation, the cellular uptake and intracellular metabolism of ${ }^{131} \mathrm{I}-\mathrm{IV}-14$ were partially inhibited by 5 -fluorouridine.

The biodistribution study with ${ }^{131} \mathrm{I}-\mathrm{IV}-14$ in HL60 SCID mice confirmed the highly selective retention of radioactivity in tumor tissue. The UCK2 specificity of the 
retention was supported by high level of UCK2 expression in HL60 xenografts and not in normal tissue. Analysis of metabolites supported the role of phosphorylation in selective retention of IV-14 in tumor tissue. IV-14 mono- and diphosphates were detected as main metabolic products in tumor but not in urine, blood, liver, gastrointestinal tract, and gastrointestinal tract contents. Sufficient metabolic stability is essential for successful in vivo application of a radiotracer. A study of structure-activity relationships on several 3 '-substituted uridines and cytidines (24) showed that besides $3^{\prime}$-(ethynyl)uridine and 3 '-(ethynyl)cytidine, only 3'-propenyluridine and 3 '-vinylcytidine could be phosphorylated by UCK at an appreciable rate. On the basis of these data, $3^{\prime}$-iodoethenyluridine should be an apparent choice because of the comparable bulkiness and electronic properties of iodine and a methyl group. However, preliminary experiments showed that radioiodinated iodoethynyl-substituted nucleosides were rapidly deiodinated in human blood serum. Therefore, we synthesized an iodovinyl-substituted nucleoside, IV-14, which demonstrated excellent stability in serum. Furthermore, it was also stable toward human thymidine phosphorylase, which was described to have a broad specificity and contributed to cleavage not only of $2^{\prime}$-deoxyribonucleosides but also of ribonucleosides (25). In contrast, human uridine phosphorylase is highly specific to uridine and is responsible only for $15 \%-20 \%$ cleavage of 5-fluorouridine in blood (26). In contrast to human enzymes, murine uridine phosphorylases play a main role in cleavage of nucleosides in mice $(26,27)$. Appropriate tests showed high stability of IV-14 also toward murine uridine phosphorylases. Surprisingly, in HL60-xenografted SCID mice we observed a high radioactivity concentration in stomach content. Analysis of metabolites showed, along with unchanged IV-14, a significant quantity of radioiodide, indicating deiodination of IV-14 in vivo. This finding was in marked contrast to the good stability of IV-14 toward deiodination in vitro. The mechanism of this deiodination is unclear at present.

Low incorporation of IV-14 in RNA and DNA could explain significant washout of the tracer from the tumor with time. Indeed, nucleoside mono-, di-, and triphosphates could potentially be released via binding cassette transporters and some other transporters as well as during exocytosis (28). It has been also shown that the increased efflux of nucleoside monophosphates via $\mathrm{ABCC}$ transporters (ATP-binding cassette transporters, subfamily C) - that is, multidrug resistant proteins 4,5 , and 8 -contributes to the resistance of tumor cells against nucleoside drugs $(29,30)$. Nucleoside tri-, di-, and monophosphates could also be hydrolyzed by nucleoside diphosphohydrolases (31) and $5^{\prime}$-nucleosidases (32). Since only intact nucleoside and radioiodide were found in blood, urine, and stomach content, hydrolysis by $5^{\prime}$-nucleosidase followed by efflux via $\mathrm{hENT}_{1}$ transporters could be a more plausible explanation for the washout of IV-14 from the tumor.
$\mathrm{hENT}_{1}$ equilibrating nucleoside transporters play an important role in the intracellular transport of the different nucleosides, such as $3^{\prime}$-deoxy-3'-fluorothymidine, gemcitabine, cytarabine, and fludarabine $(33,34)$. We observed a significant $(2.69 \pm 0.07$ percentage injected dose) accumulation of radioactivity in HL60 cells with moderate UCK2 expression but with a high hENT $_{1}$ level after $24 \mathrm{~h}$ of incubation. The significance of $\mathrm{hENT}_{1}$ for intracellular transport of IV-14 was supported in the case of HL60 cells by a strong inhibition of cellular uptake with $p$-nitrobenzylmercaptopurine, a known inhibitor of $\mathrm{hENT}_{1}$. However, the only moderate inhibition of cellular uptake of IV-14 with $p$-nitrobenzylmercaptopurine observed for MiaPaCa- 2 cells suggests possible alternative mechanisms for the intracellular transport of IV-14 in different cell lines.

\section{CONCLUSION}

In this study, we showed that cellular retention of IV-14 is strongly dependent on UCK2 expression and its activity, since the protein level correlates with the enzymatic activity (10). A new uridine analog, IV-14, is also selectively taken up by UCK2-expressing HL60 tumor tissue, indicating potential for imaging UCK2-positive tumors in vivo.

\section{ACKNOWLEDGMENTS}

Prof. Stephan Hahn (Bochum, Germany) is gratefully acknowledged for a generous gift of BX-PC-3, Mia-PaCa-2, Panc-1, and SK-PC-1 cells. We also thank Dr. Annette Sommer (Bayer-Schering, Berlin, Germany) for data on messenger RNA expression of UCK2, Profs. Hans-Jürgen Machulla (Tübingen, Germany) and Gerhard Glatting for critical reading of the manuscript, and Manuela Pape and Ehab Al Mamoni for excellent technical assistance. This work was supported in part by the European Community's FP6 funding (MolDiag-PaCa). This publication reflects only the authors' views. The European Community is not liable for any use that may be made of the information herein.

\section{REFERENCES}

1. Wiebe LI. Applications of nucleoside-based molecular probes for the in vivo assessment of tumor biochemistry using positron emission tomography (PET). Braz Arch Biol Technol. 2007;50:445-459.

2. Mercer JR. Molecular imaging agents for clinical positron emission tomography in oncology other than fluorodeoxyglucose (FDG): applications, limitations and potential. J Pharm Pharm Sci. 2007;10:180-202.

3. Karagiannis TC. Auger electron emitting isotopes in cancer therapy: cellular effects and therapeutic potential of ${ }^{125}$ I. J Hell Nucl Med. 2004;7:111-116.

4. Toyohara J, Fujibayashi Y. Trends in nucleoside tracers for PET imaging of cell proliferation. Nucl Med Biol. 2003;30:681-685.

5. Buck AK, Herrmann K, Büschenfelde CM, et al. Imaging bone and soft tissue tumors with the proliferation marker $\left[{ }^{18} \mathrm{~F}\right]$ fluorodeoxythymidine. Clin Cancer Res. 2008;14:2970-2977.

6. Ishiwata K, Ido T, Matsuzawa T, Murakami M. Studies on ${ }^{18} \mathrm{~F}$-labeled pyrimidines III: biochemical investigation of ${ }^{18} \mathrm{~F}$-labeled pyrimidines and comparison with ${ }^{3} \mathrm{H}$-deoxythymidine in tumor-bearing rats and mice. Eur $J$ Nucl Med. 1985;10:39-44.

7. Takatori S, Kanda H, Takenaka K, et al. Antitumor mechanisms and metabolism of the novel antitumor nucleoside analogues, 1-(3- $C$-ethynyl- $\beta$-D-ribo-pentofuranosyl)cytosine and 1-(3-C-ethynyl- $\beta$-D-ribo-pentofuranosyl)uracyl. Cancer Chemother Pharmacol. 1999;44:97-104. 
8. Bayés M, Rabasseda X. Gateways to clinical trials. Methods Find Exp Clin Pharmacol. 2008;30:67-79.

9. Yokogawa T, Naito T, Kanda H. Inhibitory mechanisms of 1-(3- $C$-ethynyl- $\beta$-Dribo-pentofuranosyl)uracyl (EUrd) on RNA synthesis. Nucleosides Nucleotides Nucleic Acids. 2005;24:227-232.

10. Shimamoto Y, Kazuno H, Murakami Y, et al. Cellular and biochemical mechanisms of the resistance of human cancer cells to a new anticancer ribonucleoside, TAS-106. Jpn J Cancer Res. 2002;93:445-452.

11. Van Rompay AR, Norda A, Lindén K, Johansson M, Karlsson A. Phosphorylation of uridine and cytidine nucleoside analogs by two human uridine-cytidine kinases. Mol Pharmacol. 2001;59:1181-1186.

12. Murata D, Endo Y, Obata T, et al. A crucial role of uridine/cytidine kinase 2 in antitumor activity of $3^{\prime}$-ethynyl nucleosides. Drug Metab Dispos. 2004;32:11781182 .

13. Ozaki K, Kuroki T, Hayashi S, Nakamura Y. Isolation of three testis-specific genes (TSA303, TSA806, TSA903) by a differential mRNA display method. Genomics. 1996;36:316-319.

14. Jung PMJ, Burger A, Biellmann J. Diastereofacial selective addition of ethynylcerium reagent and Barton-McCombie reaction as the key steps for the synthesis of $C$-3'-etynylribonucleosides and of $C$-3'-etynyl-2'-deoxyribonucleosides. J Org Chem. 1997;62:8309-8314.

15. Bradford MM. A rapid and sensitive method for the quantitation of microgram quantities of protein utilizing the principle of protein-dye binding. Anal Biochem. 1976;72:248-254.

16. Toyohara J, Hayashi A, Sato M, et al. Rationale of $5-{ }^{125}$ I-iodo-4'-thio2 '-deoxyuridine as a potential iodinated proliferation marker. $\mathrm{J} \mathrm{Nucl} \mathrm{Med}$. 2002;43:1218-1226.

17. Jamieson GP, Brocklebank AM, Snook MB, et al. Flow cytometric quantitation of nucleoside transporter sites on human leukemic cells. Cytometry. 1993;14: $32-38$.

18. Zhang HX, Guibe F, Balavoine G. Palladium- and molybdenum-catalyzed hydrostannation of alkynes: a novel access to regio- and stereodefined vinylstannanes. J Org Chem. 1990;55:1857-1867.

19. Visser F, Sun L, Damaraju V, et al. Residues 334 and 338 in transmembrane segment 8 of human equilibrative nucleoside transporter 1 are important determinants of inhibitor sensitivity, protein folding, and catalytic turnover. J Biol Chem. 2007;282:14148-14157.

20. Reske SN, Deisenhofer S, Glatting G, et al. ${ }^{123}$ I-ITdU-mediated nanoirradiation of DNA efficiently induces cell kill in HL60 leukemia cells and in doxorubicin-, $\beta-$, or $\gamma$-radiation-resistant cell lines. J Nucl Med. 2007;48:1000-1007.
21. Buchegger F, Adamer F, Schaffland AO, et al. Highly efficient DNA incorporation of intratumourally injected $\left[{ }^{125} \mathrm{I}\right]$ iododeoxyuridine under thymidine synthesis blocking in human glioblastoma xenografts. Int J Cancer. 2004;110:145-149.

22. Young JD, Yao SYM, Sun L, Cass CE, Baldwin SA. Human equilibrative nucleoside transporter (ENT) family of nucleoside and nucleobase transporter proteins. Xenobiotica. 2008;38:995-1021.

23. Reichard P, Sköld O. Enzymes of uracil metabolisms in the Ehrlich ascites tumour in mammalian liver. Biochim Biophys Acta. 1958;28:376-385.

24. Hattori H, Nozawa E, Iino T, et al. Nucleosides and nucleotides. 175. Structural requirements for the sugar moiety for the antitumor activities of new nucleoside antimetabolites, 1-(3- $C$-ethynyl- $\beta$-D-ribo-pentofuranosyl)cytosine and -uracil. J Med Chem. 1998;41:2892-2902.

25. el Kouni MH, el Kouni MM, Naguib FNM. Differences in activities and substrate specificity of human and murine pyrimidine nucleoside phosphorylases: implications for chemotherapy with 5-fluoropyrimidines. Cancer Res. 1993;53:3687-3693.

26. Temmink $\mathrm{OH}$, de Bruin M, Laan AC, et al. The role of thymidine phosphorylase and uridine phosphorylase in (fluoro)pyrimidine metabolism in peripheral blood mononuclear cells. Int J Biochem Cell Biol. 2006;38:1759-1765.

27. Zhang Y, Rapa JJ, Inoue Y, Hayhurst GP, Gonzalez FJ, Mangelsdorf DJ. Identification of a liver-specific uridine phosphorylase that is regulated by multiple lipid-sensing nuclear receptors. Mol Endocrinol. 2004;18:851-862.

28. Lazarowski ER, Boucher RC, Harden TK. Mechanisms of release of nucleotides and integration of their action as $\mathrm{P} 2 \mathrm{X}$ - and P2Y-receptor activating molecules. Mol Pharmacol. 2003;64:785-795.

29. Guo Y, Köck K, Ritter CA et al. Expression of ABCC-type nucleotide exporters in blasts of adult acute myeloid leukemia: relation to long-term survival. Clin Cancer Res. 2009;15:1762-1769.

30. Reid G, Wielinga P, Zelcer $\mathrm{N}$, et al. Characterization of the transport of nucleoside analog drugs by the human multidrug resistance proteins MRP4 and MRP5. Mol Pharmacol. 2003;63:1094-1103.

31. Failer BU, Braun N, Zimmermann H. Cloning, expression, and functional characterization of a $\mathrm{Ca} 2+$-dependent endoplasmic reticulum nucleoside diphosphatase. J Biol Chem. 2002;277:36978-36986.

32. Hunsucker SA, Mitchell BS, Spychala J. The 5'-nucleotidases as regulators of nucleotide and drug metabolism. Pharmacol Ther. 2005;107:1-30.

33. Paproski RJ, Ng AML, Yao SYM, Graham K, Young JD, Cass CE. The role of human nucleoside transporters in uptake of $3^{\prime}$-deoxy-3'-fluorothymidine. Mol Pharmacol. 2008;74:1372-1380.

34. Kong W, Engel K, Wang J. Mammalian nucleoside transporters. Curr Drug Metab. 2004;5:63-84. 